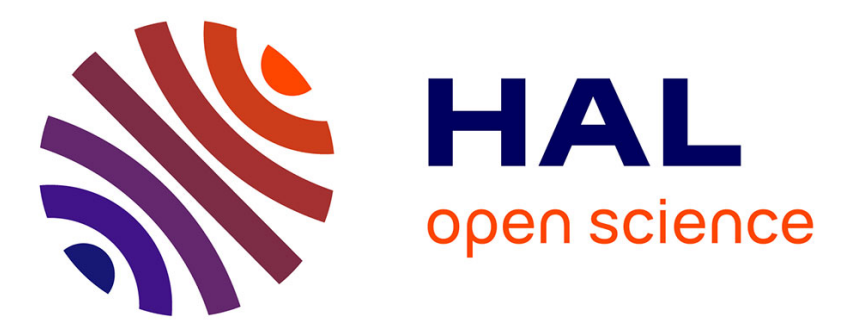

\title{
Cadmium in the food chain nearby non-ferrous metal production sites
}

Valérie Vromman, Claude Saegerman, Luc Pussemier, André Huyghebaert, Ludwig de Temmerman, Jean-Christophe Pizzolon, Nadia Waegeneers

\section{- To cite this version:}

Valérie Vromman, Claude Saegerman, Luc Pussemier, André Huyghebaert, Ludwig de Temmerman, et al.. Cadmium in the food chain nearby non-ferrous metal production sites. Food Additives and Contaminants, 2008, 25 (03), pp.293-301. 10.1080/02652030701509980 . hal-00577476

\section{HAL Id: hal-00577476 https://hal.science/hal-00577476}

Submitted on 17 Mar 2011

HAL is a multi-disciplinary open access archive for the deposit and dissemination of scientific research documents, whether they are published or not. The documents may come from teaching and research institutions in France or abroad, or from public or private research centers.
L'archive ouverte pluridisciplinaire HAL, est destinée au dépôt et à la diffusion de documents scientifiques de niveau recherche, publiés ou non, émanant des établissements d'enseignement et de recherche français ou étrangers, des laboratoires publics ou privés. 


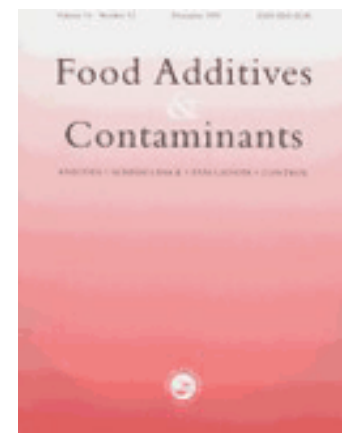

\section{Cadmium in the food chain nearby non-ferrous metal production sites}

\begin{tabular}{|c|c|}
\hline Journal: & Food Additives and Contaminants \\
\hline Manuscript ID: & TFAC-2007-091.R1 \\
\hline Manuscript Type: & Original Research Paper \\
\hline $\begin{array}{r}\text { Date Submitted by the } \\
\text { Author: }\end{array}$ & 07-Jun-2007 \\
\hline Complete List of Authors: & $\begin{array}{l}\text { Vromman, Valérie; FASFC, DG Control Policy, Secretariat of the } \\
\text { Scientific Committee } \\
\text { Saegerman, Claude; University of Liege, Faculty of Veterinary } \\
\text { Medecine, Department of Infectious and Parasitic Diseases, } \\
\text { Epidemiology and Risk analysis applied to Veterinary sciences } \\
\text { Pussemier, Luc; Veterinary and Agrochemical Research Centre } \\
\text { (VAR-CODA-CERVA), Department of Quality and Safety } \\
\text { Huyghebaert, André; Ghent University, Department of Food } \\
\text { Technology and Nutrition } \\
\text { De Temmerman, Ludwig; Veterinary and Agrochemical Research } \\
\text { Centre (VAR-CODA-CERVA), Department of Agro-Ecochemistry, } \\
\text { Section of Agro-Ecochemistry } \\
\text { Pizzolon, Jean-Christophe; Veterinary and Agrochemical Research } \\
\text { Centre (VAR-CODA-CERVA), Department of Agro-Ecochemistry, } \\
\text { Section of Agro-Ecochemistry } \\
\text { Waegeneers, Nadia; Veterinary and Agrochemical Research Centre } \\
\text { (VAR-CODA-CERVA), Department of Agro-Ecochemistry, Section of } \\
\text { Agro-Ecochemistry }\end{array}$ \\
\hline Methods/Techniques: & AAS, Exposure assessment, ICP/MS, Risk assessment \\
\hline Additives/Contaminants: & Heavy metals, Heavy metals - cadmium \\
\hline Food Types: & Animal products - meat, Fruit, Potatoes, Vegetables \\
\hline
\end{tabular}




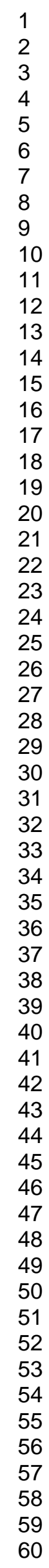

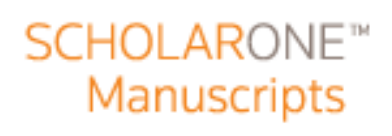

7

25

26

27

29

30

32

33

34

35

36

37

39

40

41

42

44

45

46

47

48

50

51

53

54

55

57

58

59

60

http://mc.manuscriptcentral.com/tfac Email: fac@tandf.co.uk 


\title{
Cadmium in the food chain nearby non-ferrous metal production sites
}

\author{
V. VROMMAN ${ }^{1 *}$, C. SAEGERMAN ${ }^{2}$, L. PUSSEMIER ${ }^{3}$, A. HUYGHEBAERT ${ }^{4}$, L. DE \\ TEMMERMAN $^{3}$, J.-C. PIZZOLON ${ }^{3} \&$ N. WAEGENEERS ${ }^{3}$
}

1 Federal Agency for the Safety of the Food Chain, Administration of Control Policy, Secretariat of the Scientific Committee, Brussels, Belgium

2 Department of Infectious and Parasitic Diseases, Epidemiology and Risk analysis applied to Veterinary sciences, Faculty of Veterinary Medicine, University of Liege Boulevard de Colonster, 20, B43b, B-4000 Liege, Belgium.

3 Veterinary and Agrochemical Research Centre (VAR-CODA-CERVA), Leuvensesteenweg 17, 3080 Tervuren

4 Department of Food Technology and Nutrition, Ghent University, Coupure Links 653, B-9000 Ghent, Belgium.

\begin{abstract}
Dietary cadmium (Cd) exposure was estimated for adults living in $\mathrm{Cd}$ contaminated areas close to non ferrous metal plants, and compared with the dietary $\mathrm{Cd}$ exposure of the general Belgian adult population. To evaluate the contamination levels of locally produced food items, 35 fruit samples, 97 vegetable samples and 98 samples of potatoes and 53 samples of meat, liver and kidneys of cattle that had resided for more than 18 months in the contaminated area, were analysed for Cd. Mean $\mathrm{Cd}$ concentrations in fruit and vegetables were 1.1- to 9-fold higher than in samples from other regions at ambient $\mathrm{Cd}$ levels. Mean Cd concentrations in bovine meat, liver and kidneys were two-fold higher compared to samples from animals of other regions in Belgium. The estimated dietary intake was 31.3 and $63.3 \mu \mathrm{g} \mathrm{day}^{-1}$ for average and large consumers in the contaminated area, compared to 17 and $38.3 \mu \mathrm{g}_{\text {day }}{ }^{-1}$ for the general adult population. Extensive consumption of locally produced food items in areas close to non-ferrous metal plants could result in Cd intake levels exceeding the provisional tolerable weekly intake (PTWI).
\end{abstract}

Keywords : cadmium, dietary intake, risk assessment, pollution, cattle, vegetables. 


\section{Introduction}

The level of cadmium reflects the level of industrial pollution of the local environment (Saegerman et al. 2006). During previous decades numerous non-ferrous metal production plants have been installed in industrialized countries. In Belgium, many industrial sites were created for the production and treatment of non-ferrous metals. As such, several zinc and copper smelters emerged in the Northern part of the country (Campine region). One of the adverse consequences originating from these activities is the mainly historical, local emission into air, water and soil of large amounts of contaminants such as cadmium (Cd), for which Belgium was one of the principal producers in Europe (Monography 2004). Cadmium can also occur naturally in the environment from the gradual process of erosion and abrasion of rocks and soils, and from singular events such as forest fires and volcanic eruptions. It is therefore naturally present everywhere in air, water, soils and foodstuffs (http://www.cadmium.org/introduction.html). In the last decades considerable attention was drawn to the toxicological effects resulting from the contamination of the local environment by heavy metals (Saegerman et al. 2006; Mench et al. 1989; Marshall and Mellinger 1980). As a consequence, progress was made in the control of emissions of these toxic elements by the industry and large efforts were (and are still) devoted for remediation actions. These remediation actions mainly concern the industrial area itself and nearby private gardens where high metal concentrations were measured. Less attention has been paid to areas a few kilometers away from the industrial sites where lower but still increased metal levels have been detected in several environmental compartments (Staessen et al. 1994; IHE 1986). These areas are typically situated within a few tens of kilometers around the industrial sites and may still form a risk for the contamination of the food chain and, as a possible consequence, for human health. Residents of six contaminated districts close to three smelters in the Campine region had higher urinary $\mathrm{Cd}$ excretion, a biomarker of lifetime exposure, than residents from four other districts (Staessen et al. 1994; Staessen et al. 1999). Furthermore, residence in a more contaminated district rather than a less contaminated district increased the risk of bone fractures (Staessen et al. 1999). Recently it was found that overall cancer risk was significantly associated with a doubling of 24-h cadmium excretion (Nawrot et al. 2006). In all of the ten districts, Cd in the soil was positively correlated with Cd in vegetables and in the residents' urine (Staessen et al. 1994).

The major routes of $\mathrm{Cd}$ transfer to humans via the food chain are illustrated in Figure 1. Soils are contaminated by $\mathrm{Cd}$ through wet and dry deposition of $\mathrm{Cd}$ emissions. The contaminated soil, in turn, can be at the origin of groundwater pollution (up to $400 \mathrm{\mu g} \mathrm{I}^{-1}$ in wells located in the Campine region; IHE 1986) and of locally grown crops (fodder crops such as maize and grass as well as vegetables such as potatoes, carrots, cabbages). The fodder crops are fed to cattle, which accumulate $\mathrm{Cd}$ in specific organs such as kidneys and liver (López Alonso et al. 2000). At the top of the food chain, the consumer of locally produced foodstuffs will be particularly exposed mostly 
via the consumption of animal products (especially the organs) and vegetables (mostly broad-leaf and root vegetables).

The objective of this study was to estimate human Cd exposure through the food chain in some areas of Northern Belgium which are close to non-ferrous metal plants. Information was collected on $\mathrm{Cd}$ concentrations measured in vegetables and animal products produced in these areas and other regions in Belgium. Next, dietary $\mathrm{Cd}$ intake was calculated for the consumers of these locally produced food items and compared to the dietary intake of the general adult population in Belgium.

[Insert figure 1 about here]

\section{Materials and methods}

\section{Sampling}

The contaminated area is situated in the North of Belgium, around several non-ferrous metal production sites with known Cd emissions. The surface area contaminated with $\mathrm{Cd}$ is about 1200 $\mathrm{km}^{2}$ or $4 \%$ of the total Belgian surface area.

Vegetable and animal food products have been sampled in the period 2004-2005 by the Belgian Federal Agency for the Safety of the Food Chain (FASFC), both in the contaminated area and in "uncontaminated" areas of Belgium, i.e. areas at ambient environmental Cd levels. The number of samples taken by the FASFC is determined in the official control program. The methodology developed for the program is based on risk evaluation, statistical tools and current scientific knowledge (Maudoux et al. 2006). Vegetable food products included strawberries, berries, cabbages, beans, asparagus, carrots, scorzonera, celery, leek and potatoes. Field sampling of these fruits and vegetables was carried out just before harvest of the crops. Samples were taken close to the emission sources and at increasing distances (within a radius from 4 up to $10 \mathrm{~km}$ ). Animal food products (kidney, liver and meat) were sampled at random in slaughterhouses by FASFC in 2005. Tissues were sampled both from animals that had resided more than 18 months in the contaminated area, and from animals that resided in areas at ambient environmental Cd levels.

\section{Analytical methods}

The vegetable samples were grinded before analysis. Only edible parts of the foods were used. Potato tubers, carrots and scorzonera roots were washed thoroughly and peeled first. The method for the analysis of vegetable samples is derived from the EN 14084:2002 "Foodstuffs - 
Determination of trace elements -Determination of lead, cadmium, zinc and iron by atomic absorption spectrometry (AAS) after microwave digestion". The homogenized samples were microwave digested with nitric acid and hydrogen peroxide. The concentration of cadmium was quantified by mean of AAS graphite furnace. Each batch of 8 samples in duplicate additionally included two procedure blanks and at least 2 certified reference materials. In case of deviations from a set of common criteria for values obtained for the blanks and the reference materials, the analyses in that batch had to be repeated.

The limit of quantification (LOQ) for Cd was derived from inter laboratory reproducibility tests on real samples with very low concentrations of cadmium and calculated as $L O Q=\sqrt{2} \cdot 6 . s_{R}$ where $S_{R}$ represents the intra-reproducible standard deviation (VITO 2005) and equals $0.01 \mathrm{mg} \mathrm{kg}^{-1}$. Analytical results below the $L O Q$ were (reported < LOQ) set equal to the $L O Q / 2$ for data analysis purposes (half weight bound principle). The analysis were carry out in the laboratory of the FASFC located in Gentbrugge.

The animal tissues were stored in a freezer until analysis. The tissues were mixed in a home mixer to homogenize the samples. Consequently the kidney cortex and medulla, which contain unequal trace element concentrations, were homogeneously mixed and the $\mathrm{Cd}$ concentrations were expressed on the whole organ. For each tissue, two homogenized subsamples were microwave digested with nitric acid at $180^{\circ} \mathrm{C}$, and $\mathrm{Cd}$ concentrations in all samples were quantified by inductively coupled plasma-mass spectrometry (ICP-MS, VG PQExCell, TJA, US). Each batch of 20 samples additionally included one procedure blank, one certified reference material (IAEA 407) and one laboratory reference material. In case of deviations from a set of common criteria for tolerable variations of blanks, and for values obtained for the reference materials, the analyses in that batch had to be repeated. The limit of quantification (LOQ) for $\mathrm{Cd}$ was calculated as 10 times the standard deviation of ten procedure blanks, multiplied with the dilution factor, and equals $0.002 \mathrm{mg} \mathrm{kg}^{-1}$. Analytical results below the LOQ were set equal to the LOQ/2 for data analysis purposes (half weight bound principle). All Cd concentrations are expressed on a fresh weight basis.

\section{Estimation of cadmium intake}

Average $\mathrm{Cd}$ intake and large $\mathrm{Cd}$ intake were calculated both for adults living in the contaminated area (local adult population in a contaminated area) and for adults living in areas at ambient environmental $\mathrm{Cd}$ levels (general adult population). Differences in $\mathrm{Cd}$ intake between adults from both areas are based on differences in measured $\mathrm{Cd}$ concentrations in locally produced food items. Differences between average and large $\mathrm{Cd}$ intake are based on differences in daily food consumption amounts.

Food products were classified in 13 major food groups (Table I). Vegetables were subdivided conform the definitions for the European maximum levels settings (European Commission 2001). 
These subgroups are defined as (i) vegetables, excluding leafy vegetables, fresh herbs, all fungi, stem vegetables, root vegetables and potatoes, (ii) stem vegetables and root vegetables, excluding celeriac, and (iii) leafy vegetables, fresh herbs, celeriac and all cultivated fungi. The European maximum levels of $\mathrm{Cd}$ for the respective categories are (i) $0.05 \mathrm{mg} \mathrm{kg}^{-1}$, (ii) $0.1 \mathrm{mg} \mathrm{kg}^{-1}$, and (iii) 0.2 $\mathrm{mg} \mathrm{kg}^{-1}$. The daily consumption of each of the major food groups and subgroups was estimated for adults between 19 and 59 years. Several food consumption models are available. A Belgian food consumption survey was carried out in 2004 (Devriese et al. 2006). The survey is based on food frequency questionnaires and two 24h dietary recall inquiries of more than 3200 persons, and reports the median and $25^{\text {th }}, 50^{\text {th }}, 75^{\text {th }}$ and $97.5^{\text {th }}$ percentile consumption of major food groups. The results are not detailed enough to differentiate consumption within the food groups outlined in Table I. The UK Pesticides Safety Directory published a new chronic intake calculation model, the National Estimate of Dietary Intake (NEDI) model with mean and $97.5^{\text {th }}$ percentile consumption data of different food groups and subgroups (National Estimate of Dietary Intake 2006). Consumption of fish and seafood is, however, lacking in this model. The GEMS/Food regional dietary pattern of raw and semi-processed food commodities database provides five-year average intakes for most foods and for clusters of countries (World Health Organization 2006). Although dietary consumption patterns in Belgium probably won't differ to a large extent from consumption patterns in its surrounding countries, other countries with different dietary habits are included within the same cluster, e.g. Mediterranean countries, which makes the GEMS/Food database less suitable for $\mathrm{Cd}$ intake calculations in Belgium. Therefore the daily consumption of the major food groups is based on the Belgian food consumption survey (Devriese et al. 2006). The NEDI consumption data (National Estimate of Dietary Intake 2006) correspond relatively well to the Belgian food consumption survey data and were used to calculate the relative intake of food from subgroups within a major food group, and these relative values were applied on the Belgian food consumption survey data. Remaining data gaps were filled in with the GEMS/Food consumption data (World Health Organization 2006). The resulting food consumption pattern is presented in Table I.

\section{[Insert table I about here]}

Mean Cd concentrations were calculated for the major food groups or their subgroups. All measured Cd concentrations of individual food samples were averaged per (sub)group. The Cd content of food groups that had not been sampled within the framework of this study (e.g. cereals, fish, milk) were collected from literature (Beernaert et al. 1990; SCOOP 2004) or from other data gained by the FASFC (unpublished results).

Average dietary $\mathrm{Cd}$ intake $\left(\mu \mathrm{g} \mathrm{day}^{-1}\right)$ was calculated by multiplying the average $\mathrm{Cd}$ concentration in each food (sub)group $\left(\mu \mathrm{g} \mathrm{kg}^{-1}\right.$ ) by the average daily consumed weight of that food (sub)group $\left(\mathrm{kg} \mathrm{day}^{-1}\right)$. Large dietary $\mathrm{Cd}$ intake was calculated by using the $97.5^{\text {th }}$ percentile 
consumption value for each food (sub)group. In general, average Cd concentrations and the half weight bound principle (i.e. concentrations < LOQ are set equal to $L O Q / 2$ ) were used in intake calculations because this methodology is recognized as giving a realistic and appropriate estimate of long-term exposure. In order to make comparisons possible, some calculations were also carried out using the median $\mathrm{Cd}$ concentration and the high weight bound principle (i.e. results < LOQ are considered equal to the LOQ).

The daily dietary Cd intake was compared with the provisional tolerable weekly intake (PTWI) of $7 \mu \mathrm{g} / \mathrm{kg}$ bw per week (World Health Organization 2001) for a 60-kg adult as

$\%$ PTWI $=\frac{\text { daily dietary } \mathrm{Cd} \text { intake }\left(\mu \mathrm{g} \mathrm{day}^{-1}\right) \cdot 7(\text { day })}{7\left(\mu \mathrm{g} \mathrm{kg}_{\mathrm{bw}}^{-1}\right) \cdot 60(\mathrm{~kg})} \cdot 100 \%$

Only a deterministic approach has been applied because of the absence of recent, publicly available, individual consumption data that are representative for the Belgian population. This approach gives a realistic fraction of the PTWI to which consumers of food products that are locally produced around non ferrous metal production sites, are exposed.

\section{Statistical analysis}

The mean of the quantitative parameters in each group with unequal variance was compared with Welch's test (Dagnelie 1998). The limit of statistical significance of the conducted tests was defined as $P \leq 0.05$.

\section{Results}

\section{Cadmium in vegetable and animal food products}

The mean Cd concentrations analyzed in fruits, vegetables and potatoes that are sampled in the contaminated area are significantly larger (1.1- to 9-fold) than in the samples from other regions in Belgium at ambient environmental Cd concentrations (Welch'test; $P \leq 0.001$ ) (Table II). The largest increase in $\mathrm{Cd}$ content is found for stem and root vegetables and for leafy vegetables. The average $\mathrm{Cd}$ concentration in leafy vegetables from contaminated area is above the European maximum level of $0.2 \mathrm{mg} \mathrm{kg}^{-1}$ fresh weight. About $60 \%$ of vegetables (standard $0.2 \mathrm{mg} \mathrm{kg}^{-1}$ ) from the contaminated area were above the European maximum level. About $3 \%$ of vegetables (standard $0.2 \mathrm{mg} \mathrm{kg}^{-1}$ ) exceeded the European maximum level in other regions in Belgium. About $40 \%$ of vegetable (standard $0.1 \mathrm{mg} \mathrm{kg}^{-1}$ ) from the contaminated area exceeded the maximum level. Also $6 \%$ of the potatoes from the contaminated area were above the European maximum 
level. About $3 \%$ of the vegetables (standard $0.2 \mathrm{mg} \mathrm{kg}^{-1}$ ) exceeded the European maximum level in other regions in Belgium. Potatoes and vegetables (standard $0.1 \mathrm{mg} \mathrm{kg}^{-1}$ ) from other regions in Belgium were below the European maximum level.

The mean $\mathrm{Cd}$ concentrations analyzed in meat, liver and kidney that are sampled in the contaminated area are significantly larger (twofold) than in the samples from other regions in Belgium at ambient environmental Cd concentrations (Welch'test; $P \leq 0.001$ ). The average $\mathrm{Cd}$ concentration in kidneys of bovine animals, both from contaminated and uncontaminated areas, exceeds the European maximum level of $1.0 \mathrm{mg} \mathrm{kg}^{-1}$ fresh weight (Table II). About $75 \%$ of the kidneys from the contaminated area were above the maximum level and were not suitable to enter the food chain. Also $50 \%$ of the kidneys from other regions in Belgium surpassed the limit value. The average $\mathrm{Cd}$ concentration in livers from the contaminated area is close to the European maximum level of $0.5 \mathrm{mg} \mathrm{kg}^{-1}$ fresh weight, $25 \%$ of the samples were above the limit value. Six percent of livers from other regions in Belgium were above the European maximum level. Cadmium concentrations were, however, far below the European maximum level of $0.05 \mathrm{mg} \mathrm{kg}^{-1}$ fresh weight in all meat samples from Belgian cattle.

\section{[Insert table II about here]}

\section{Dietary Cd intake}

Dietary Cd intake was calculated for adult populations (19-59 years; assumed mean weight $60 \mathrm{~kg}$ ) living in the $\mathrm{Cd}$ contaminated area or living somewhere else in Belgium, i.e. at ambient environmental $\mathrm{Cd}$ levels. It was assumed that the vegetables, potatoes and small fruit (berries) consumed by adults living in the contaminated area, were locally produced. As a large number of cattle farms are established in the contaminated area, it was also assumed that the consumed cattle meat and offal was locally produced. In general, this meat is nationally distributed, but farmers might have slaughtered some of their cattle for private consumption (e.g. Saegerman et al. 2002). At average food consumption levels (Table I), adults living in the Cd contaminated area have an estimated daily Cd intake of $31 \mu \mathrm{g} \mathrm{day}^{-1}$ (Table III), which is almost double the estimated intake of the general adult population (17 $\mu \mathrm{g} \mathrm{day}^{-1}$; Table IV). Potatoes consumption is responsible for $46 \%$ of the daily Cd intake in the contaminated area and accounts for $24 \%$ of the PTWI (Table III). The Cd content of potatoes is lower at ambient environmental Cd levels, as a result of which they only contribute for $10 \%$ of the PTWI in those areas (Table IV). Other major contributors to the average daily $\mathrm{Cd}$ intake are vegetables and cereals. Despite the large $\mathrm{Cd}$ concentrations found in cattle offal, their contribution to the daily Cd intake is negligible (Table III \& IV). The percentage of 
the PTWI due to cattle offal consumption is less than $0.1 \%$, regardless the environmental $\mathrm{Cd}$ levels.

The influence of the variability in food consumption on $\mathrm{Cd}$ intake is taken into account by calculating the daily $\mathrm{Cd}$ intake based on a $97.5^{\text {th }}$ percentile consumption pattern (Table I). With a daily $\mathrm{Cd}$ intake of $38.3 \mu \mathrm{g} \mathrm{day}^{-1}$, the general adult population in Belgium reaches $63.8 \%$ of the PTWI (Table IV). Adults consuming locally produced food items in the Cd contaminated area would have an estimated daily $\mathrm{Cd}$ intake of $63.3 \mu \mathrm{g}_{\text {day }}{ }^{-1}$ (Table III). This is more than the provisional tolerable intake level for a $60-\mathrm{kg}$ person, for $105.5 \%$ of the PTWI is reached at this exposure scenario. Potatoes and cereals remain the most important sources of $\mathrm{Cd}$ intake, together they account for $32 \%$ of the PTWI in the general population and $55 \%$ of the PTWI for the local population in the contaminated area.

\section{[Insert table III about here]}

[Insert table IV about here]

\section{Discussion}

The dietary Cd intake of the general adult population in Belgium, estimated at $17 \mu \mathrm{g}$ day $^{-1}$, is comparable to earlier published mean intake data of $23.1 \mu \mathrm{g} \mathrm{day}^{-1}$ (range 13.4-41.8 $\mu \mathrm{g} \mathrm{day}^{-1}$; Van Cauwenbergh et al. 2000) and $18 \mu \mathrm{g} \mathrm{day}^{-1}$ (range 2.1-88.1 $\mu \mathrm{g} \mathrm{day}^{-1}$; Buchet et al. 1983). Although these $\mathrm{Cd}$ intake values are based on duplicate meals, they confirm that the $\mathrm{Cd}$ intake for the general adult population in this study is a realistic estimate. The dietary exposure estimate is also close to recent estimates from the United Kingdom: $14 \mu \mathrm{g}$ day ${ }^{-1}$ (Ysart et al. 2000); Denmark: 16 $\mu \mathrm{g}$ day $^{-1}$ (Larsen et al. 2002); Tarragona, Spain: $14.3 \mu$ day $^{-1}$ (Bocio et al. 2005); Catalonia, Spain: 12.03-15.73 $\mu \mathrm{g} \mathrm{day}^{-1}$ for females- males (Llobet et al. 2003), but 6-fold larger than the most recent dietary exposure estimate in France: $2.7 \mu \mathrm{g} \mathrm{d}^{-1}$ (Leblanc et al. 2005).

Potatoes, cereals and vegetables are the main sources of $\mathrm{Cd}$ for the Belgian adult population together they provide $71 \%$ of the daily $\mathrm{Cd}$ intake. The large consumption amount of these food groups and the larger $\mathrm{Cd}$ content of potatoes and vegetables in the contaminated area results in a large average daily $\mathrm{Cd}$ intake in the contaminated area, corresponding to $44 \%$ of the PTWI. Although the mean $\mathrm{Cd}$ concentration in potatoes and vegetables produced in the contaminated area was below the European maximum levels, several samples exceeded this value. The high $\mathrm{Cd}$ concentrations in cattle offal are relatively unimportant in terms of $\mathrm{Cd}$ intake due to its low consumption, even in the large consumption scenario. However, the consumption data are based on the general population. Assuming that offal is eaten as a replacement of meat, i.e. $143 \mathrm{~g}$ meat is replaced by an equal amount of liver or kidney, it can be calculated that the large figures for 
cattle liver and kidney consumption presented in Table I correspond to two portions of cattle liver per year and one portion of cattle kidneys every two years. These figures might be realistic for average Belgian adults between 19 and 59 years. It is, however, not unlikely that some people, and especially cattle farmers, consume more regularly livers or kidneys. In case cattle liver, originating from the contaminated area, is eaten at a ration of once per month, this would increase the average weekly intake of Cd with $14.9 \mu \mathrm{g}$, or $3.5 \%$ of the PTWI. One portion of cattle kidneys per month would increase the average weekly Cd intake with $95.5 \mu \mathrm{g}$ or $22.7 \%$ of the PTWI. Thus, the high $\mathrm{Cd}$ concentrations in cattle offal are not that unimportant. Actions have been taken by the federal government, which involve a ban on bringing kidneys of bovine animals that resided at least 18 months in the contaminated area, into the food chain for human consumption, and a ban on the export of such animals. Furthermore, offal that is suspected to contain contaminants in such amounts that there might be a risk for the consumer's health can be confiscated.

For the local adult population in a contaminated area as well for the general adult population, the intake is twofold larger for large consumption scenario compared to average consumption scenario. Hence, the large consumption scenario in the contaminated area reveals that more than $100 \%$ of the PTWI of Cd would be consumed. It might be argued that not all food groups would be consumed at such large amounts at the same time. However, a Cd intake of $38.3 \mu \mathrm{g}$ day $^{-1}$ for the general population falls within the range of daily $\mathrm{Cd}$ intakes measured in the duplicate meal study of Van Cauwenbergh et al. (2000). The Cd intake estimation in the contaminated area assumes that $100 \%$ of several food groups are produced in the area, which is an extreme but not unreal assumption.

Less than $50 \%$ of results were below the LOQ. According to WHO (1995), if the proportion of results $\angle \mathrm{LOD}$ is $\leq .60 \%$, LOD/2 should be used for all results less than LOD. The LOD is meaningless in the case of determination by ICP-MS. Hence, for the intake calculations, results $<L O Q$ were set equal to LOQ/2 (i.e. half weight bound principle). If we use the high weight bound principle (i.e. results $\angle L O Q$ are considered equal to the $L O Q$ ), the percentage of the PTWI reached is slightly higher (+ 4\%). Moreover mean Cd concentration was used for the intake calculations. The percentage of PTWI reached when the mean Cd concentration is replaced by the median concentration in intake calculation is slightly lower (- $7 \%$ ). In this case, the PTWI is $98.1 \%$ instead of $105.5 \%$ for a large intake scenario in the contaminated area. When both the median and high weight bound principles are applied together, the PTWI reaches $101.1 \%$ for a large intake scenario in the contaminated area. Intake estimations could be improved by applying a probabilistic approach taking into account individual variations in food consumption and/or by using a more extensive database for Cd concentrations in food items.

Historical pollution from non-ferrous smelters continues to present a serious health hazard, necessitating targeted preventive measures (Nawrot et al. 2006). 


\section{Conclusion}

A deterministic approach to determine Cd intake of an adult population living in a Cd contaminated area nearby to non-ferrous metal plants, reveals that such population might consume almost twice as much $\mathrm{Cd}$ as the general adult population in Belgium (large consumption scenario assuming that the local population will consume exclusively foodstuffs produced in the contaminated area). Cadmium intake by adults consuming large amounts of food even surpasses the PTWI. Average $\mathrm{Cd}$ concentrations in fruit, vegetables, potatoes, meat and offal are found to be larger in the contaminated area than in other regions of Belgium. It is recommended to improve $\mathrm{Cd}$ intake estimation by applying a probabilistic approach which takes into account (i) the distribution of individual consumption data of the sub-population living in the contaminated areas around non ferrous metal plants and of the general Belgian population, and (ii) geographic distribution of $\mathrm{Cd}$ concentrations in an extended array of food items. Such data are, however, not available at the moment.

\section{References}

Beernaert H, Van Rillaer W, Van der Mijnsbrugge F, Janssens G, Dhaoudi A. 1990. Bewakingsprogramma van zware metalen in levensmiddelen. Project 1989/1. Instituut voor Hygiëne en Epidemiologie, Brussel [in Dutch].

Bocio A, Nadal M, Domingo JL. 2005. Human exposure to metals through the diet in Tarragona, Spain. Biological Trace Element Research 104: 193-201.

Buchet JP, Lauwerys R, Vandevoorde A, Pycke JM. 1983. Oral daily intake of cadmium, lead, manganese, copper, chromium, mercury, calcium, zinc and arsenic in Belgium: a duplicate meal study. Food Chemistry and Toxicology 21: 19-24.

Dagnelie P. Statistique théorique et appliquée. Tome 2. Inférence statistique à une et à deux dimensions. De Boeck \& Larcier (ed.), 1998; 659 p.

Devriese S, Huybrechts I, Moreau M, Van Oyen H. 2006. De Belgische voedselconsumptiepeiling 1 - 2004: Rapport. Wetenschappelijk Instituut Volksgezondheid, maart 2006, Depotnummer : D/2006/2505/17. Available: http://www.iph.fgov.be/EPIDEMIO/epien/index5.htm via the INTERNET. Accessed 2006 November 30.

European Commission. 2001. Commission Regulation (EC) No. 466/2001 of 8 March 2001 setting maximum levels for certain contaminants in foodstuffs. Official Journal of the European Communities L77/1-13. 
Institut d'Hygiène et d'Epidémiologie (IHE). 1986. De verontreiniging van het groundwater door cadmium en zink in de gemeenten Lommel, Overpelt, Neerpelt en Dilsen. VMM Referentie: Werkgroep zware metalen in N-Limburg. Subgroup water [in Dutch].

Larsen EH, Andersen NL, Møller A, Petersen A, Mortensen GK, Petersen J. 2002. Monitoring the content and intake of trace elements from food in Denmark. Food Additives and Contaminants 19: 33-46.

Leblanc J-C, Guérin T, Noël L, Calamassi-Tran G, Volatier J-C, Verger P. 2005. Dietary exposure estimates of 18 elements from the $1^{\text {st }}$ French total diet study. Food Additives and Contaminants 22: 624-641.

Llobet JM, Falcó G, Casas C, Teixidó A, Domingo JL. 2003. Concentrations of arsenic, cadmium, mercury, and lead in common foods and estimated daily intake by children, adolescents, adults, and seniors of Catalonia, Spain. Journal of Agricultural and Food Chemistry 51: 838842.

López Alonso M, Benedito JL, Miranda M, Castillo C, Hernández J, Shore RF. 2000. Toxic and trace elements in liver, kidney and meat from cattle slaughtered in Galicia (NW Spain). Food Additives and Contaminants 17: 447-457.

Marshall JS, Mellinger DL. 1980. Dynamics of cadmium-stressed plankton communities. Canadian Journal of Fisheries and Aquatic Sciences 37: 403-414.

Maudoux JP, Saegerman C, Rettigner C, Houins G, Van Huffel X, Berkvens D. 2006. Food safety surveillance through a risk based control programme: Approach employed by the Belgian Federal Agency for the Safety of the Food Chain. Veterinary Quarterly 28(4): 140-154.

Mench M, Tancogne J, Gomez A, Juste C. 1989. Cadmium bioavailability to Nicotiana tabacum L. Nicotiana rustica L. and Zea mays L. grown in soil amended or not amended with cadmium nitrate. Biology and Fertility of Soils 8: 48-53.

Monography. 2004. Risk Assessment Cadmium oxide CAS-No 1306-9-0, EINCS No 215-146-2. Risk Assessment Cadmium metal CAS-No 7440-43-9, EINECS No 231-152-8. Final Risk Assessment Report (RAR). September 2004. Nawrot T, Plusquin M, Hogervost J, Roels HA, Celis H, Thijs, Vangronsveld J, Van Hecke E, Staessen JA. 2006. Environmental exposure to cadmium and risk of cancer: a prospective population-based study. The Lancet Oncology 7(2):119-126.

National Estimate of Dietary Intake. 2006. The National Estimate of Dietary Intake model for long term consumer intake calculations [internet]. Available from: http://www.pesticides.gov.uk/approvals.asp?id=1687. Accessed 2006 November 30. 
Saegerman C, Berkvens D, Boelaert F, Speybroeck N, Van Vlanderen I, Lomba M, Ermens A, Biront P, Broeckaert F, De Cock A, Mohimont L, Demont S, De Poorter G, Torfs B, Robijns J-M, Monfort V, Vermeersch J-P, Lengele L, Bernard A. 2002. Detection of polychlorinated biphenyls and dioxins in Belgian cattle and estimate of the maximal potential exposure in humans through diets of bovine origin. Journal of Toxicology and Environmental Health, Part A 65(18): 12891305.

Saegerman C, Pussemier L, Huyghebaert A, Scippo M-L, Berkvens D. 2006. One-farm contamination of animals with chemical contaminants. In Animal production food safety challenges in global markets (special issue). Revue Scientifique et Technique de l'OIE 25 (2): 665-681.

SCOOP. 2004. Reports on tasks for scientific cooperation. Task 3.2.11. Assessment of the dietary exposure to arsenic, cadmium, lead and mercury of the population of the EU Member states. European Commission, Directorate-General Health and Consumer Protection, March 2004. Available:

http://europa.eu.int/comm/food/food/chemicalsafety/contaminants/scoop 3-2-

11 heavy metals report en.pdf via the INTERNET. Accessed 2006 November 30.

Staessen JA, Lauwerys RR, Ide G, Roels HA, Vyncke G, Amery A. 1994. Renal function and historical environmental cadmium pollution from zinc smelters. The Lancet 343: 1523-1527.

Staessen JA, Roels HA, Emelianov D, Kuznetsova T, Thijs L, Vangronsveld J, Fagard R. 1999. Environmental exposure to cadmium, forearm bone density, and risk of fractures : prospective population study. The Lancet 353: 1140-1144.

Van Cauwenbergh R, Bosscher D, Robberecht H, Deelstra H. 2000. Daily dietary cadmium intake in Belgium using duplicate portion sampling. European Food Research and Technology 212: 13-16.

VITO. 2005. Validatie en Prestatiekenmerken. Available: http://www.vito.be/milieu/pdf/cma 2006/6A.PDF via the INTERNET. Accessed 2007 may 15.

World Health Organization. 1995. GEMS/Food - EURO Second workshop on reliable evaluation of low-level contamination of food. Kulmbach, Federal Republic of Germany, 26-27 may 1995. Available: http://www.who.int/foodsafety /publications/chem/en/lowlevel may1995.pdf via the INTERNET. Accessed 2007 may 15.

World Health Organization. 2001. Cadmium. In: Safety Evaluation of Certain Food Additives and Contaminants. Fifty-fifth meeting of the Joint FAO/WHO Expert Committee on Food Additives (JECFA). Geneva/ WHO Food Additives Series 46. pp 247-312. 
World Health Organization. 2006. GEMS/FOOD Consumption clusters diets, cluster E. Prepared by the Global Environment Monitoring System/Food Contamination Monitoring and Assessment Programme (GEMS/Food). Food Safety Department World Health Organization. June 2006. Available: http://www.who.int/foodsafety/chem/gems/en/index1.html via the INTERNET. Accessed 2006 November 30.

Ysart G, Miller P, Croasdale M, Crews H, Robb P, Baxter M, de L'Argy C, Harrison N. 2000. 1997 UK Total Diet Study - dietary exposures to aluminium, arsenic, cadmium, chromium, copper, lead, mercury, nickel, selenium, tin and zinc. Food Additives and Contaminants 17: 775-786. 


\section{Figure}

Figure 1. Main routes considered in this study for the entry of cadmium in the food chain and for the uptake by humans (----: contamination of cattle from the environment; _- contamination of humans through food consumption). 


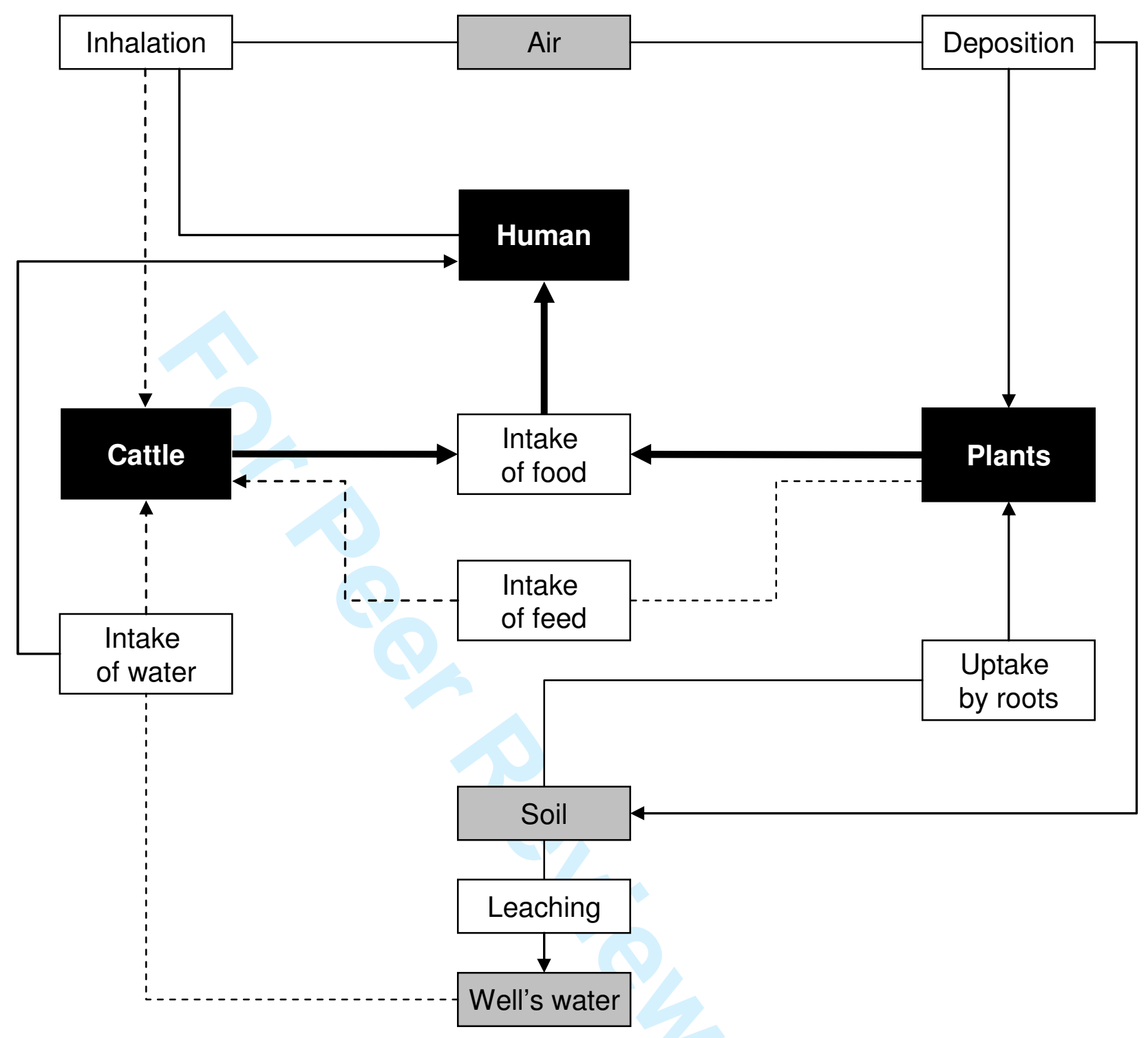

Figure 1: Main routes considered in this study for the entry of cadmium in the food chain and for the uptake by humans (----: contamination of cattle from the environment; —_: contamination of humans through food consumption). 


\section{Tables}

Table I. Average and $97.5^{\text {th }}$ percentile consumption $\left(\mathrm{kg} \mathrm{day}^{-1}\right)$ of different food groups by Belgian adults between 19 and 59 years.

Table II. Average cadmium concentration ( $\mathrm{mg} \mathrm{kg}^{-1}$ fresh weight) in fruits, vegetables bovine muscle, liver and kidney sampled in the polluted area versus other regions in Belgium at ambient environmental Cd levels. The number of samples from which the mean is calculated, is indicated between brackets.

Table III. Local adult population in a polluted area - mean Cd concentration $\left(\mathrm{mg} \mathrm{kg}^{-1}\right.$ fresh weight) of food groups, daily $\mathrm{Cd}$ intake $\left(\mu \mathrm{g} \mathrm{day}{ }^{-1}\right)$ by a $60-\mathrm{kg}$ adult living in a $\mathrm{Cd}$ polluted area, with an average consumption pattern or with a $97.5^{\text {th }}$ percentile consumption pattern, and percentage of the PTWI attained for each consumption pattern and food group.

Table IV. General adult population - mean Cd concentration ( $\mathrm{mg} \mathrm{kg}^{-1}$ fresh weight) of food groups, daily $\mathrm{Cd}$ intake $\left(\mu \mathrm{g} \mathrm{day}^{-1}\right)$ by a $60-\mathrm{kg}$ adult living in a region at ambient $\mathrm{Cd}$ 
levels, with an average consumption pattern or with a $97.5^{\text {th }}$ percentile consumption pattern, and percentage of the PTWI attained for each consumption pattern and food group. 
Table I. Average and $97.5^{\text {th }}$ percentile consumption $\left(\mathrm{kg} \mathrm{day}^{-1}\right)$ of different food groups

by Belgian adults between 19 and 59 years.

\begin{tabular}{|c|c|c|c|}
\hline \multirow{2}{*}{ Commodity } & \multicolumn{2}{|c|}{ Consumption } & \multirow[b]{2}{*}{ Data source } \\
\hline & Average & P97.5 & \\
\hline Fruit (all) & 0.111 & 0.288 & Devriese et al. 2006 \\
\hline berries & 0.006 & 0.015 & NEDI 2006 \\
\hline other fruit & 0.106 & 0.273 & $\begin{array}{l}\text { calculated from Devriese et al. } 2006 \\
\text { and NEDI } 2006\end{array}$ \\
\hline Vegetables (all) & 0.141 & 0.257 & Devriese et al. 2006 \\
\hline $\begin{array}{l}\text { vegetables } \\
\text { (standard* } 0.05 \mathrm{mg} \mathrm{kg}^{-1} \text { ) }\end{array}$ & 0.102 & 0.186 & $\begin{array}{l}\text { Calculated from Devriese et al. } 2006 \\
\text { and NEDI } 2006\end{array}$ \\
\hline $\begin{array}{l}\text { vegetables } \\
\text { (standard } 0.1 \mathrm{mg} \mathrm{kg}^{-1} \text { ) }\end{array}$ & 0.023 & 0.042 & $\begin{array}{l}\text { Calculated from Devriese et al. } 2006 \\
\text { and NEDI } 2006\end{array}$ \\
\hline $\begin{array}{l}\text { vegetables } \\
\left(\text { standard } 0.2 \mathrm{mg} \mathrm{kg}^{-1} \text { ) }\right.\end{array}$ & 0.016 & 0.030 & $\begin{array}{l}\text { Calculated from Devriese et al. } 2006 \\
\text { and NEDI } 2006\end{array}$ \\
\hline Potatoes & 0.281 & 0.466 & Devriese et al. 2006 \\
\hline Meat (all) & 0.143 & 0.285 & Devriese et al. 2006 \\
\hline poultry meat & 0.019 & 0.053 & Devriese et al. 2006 \\
\hline cattle meat & 0.068 & 0.128 & $\begin{array}{l}\text { Calculated from WHO } 2006 \\
\text { and Devriese et al. } 2006\end{array}$ \\
\hline pig meat & 0.056 & 0.104 & $\begin{array}{l}\text { Calculated from WHO } 2006 \\
\text { and Devriese et al. } 2006\end{array}$ \\
\hline Offal (all) & $3.010^{-4}$ & 0.003 & Devriese et al. 2006 and NEDI 2006 \\
\hline cattle offal & $1.210^{-4}$ & 0.001 & Calculated from WHO 2006 and NEDI 2006 \\
\hline kidney & $2.010^{-5}$ & $1.710^{-4}$ & NEDI 2006 \\
\hline liver & $9.710^{-5}$ & $8.410^{-4}$ & NEDI 2006 \\
\hline other offal & $1.810^{-4}$ & 0.002 & Calculated from WHO 2006 and NEDI 2006 \\
\hline Cereals & 0.194 & 0.402 & Devriese et al. 2006 \\
\hline Eggs & 0.010 & 0.028 & Devriese et al. 2006 \\
\hline $\begin{array}{l}\text { Milk \& milk products } \\
\text { (excluding cheese) }\end{array}$ & 0.164 & 0.483 & Devriese et al. 2006 \\
\hline Cheese & 0.032 & 0.075 & Devriese et al. 2006 \\
\hline Fish & 0.017 & 0.050 & Devriese et al. 2006 \\
\hline Seafood & 0.006 & 0.025 & Devriese et al. 2006 \\
\hline Oils and fats & 0.021 & 0.073 & Devriese et al. 2006 \\
\hline Other (e.g. sweets, sugar) & 0.295 & 0.987 & Devriese et al. 2006 \\
\hline Total & 1.417 & 3.421 & \\
\hline
\end{tabular}

*Standard refers to food or food group according to the European maximum limit. 
Table II. Average cadmium concentration ( $\mathrm{mg} \mathrm{kg}^{-1}$ fresh weight) in fruits, vegetables, bovine muscle, liver and kidney sampled in the polluted area versus other regions in Belgium at ambient environmental Cd levels. The number of samples from which the mean is calculated, is indicated between brackets.

\begin{tabular}{|c|c|c|c|c|c|c|}
\hline \multirow[b]{2}{*}{ Commodity } & \multicolumn{3}{|c|}{ Polluted area } & \multicolumn{3}{|c|}{ Regions at ambient $\mathrm{Cd}$ levels } \\
\hline & $\begin{array}{c}\text { Mean } \\
\text { (Number) }\end{array}$ & S.D. & Range & $\begin{array}{c}\text { Mean } \\
\text { (Number) }\end{array}$ & S.D. & Range \\
\hline $\begin{array}{l}\text { Berries } \\
\text { (standard* } 0.05 \text { mg kg-1) }\end{array}$ & $\begin{array}{l}0.012 \\
(\mathrm{n}=35)\end{array}$ & 0.0106 & $0.005-0.043$ & $\begin{array}{l}0.0061 \\
(\mathrm{n}=35)\end{array}$ & 0.0026 & $0.005-0.014$ \\
\hline Strawberries & $\begin{array}{l}0.012 \\
(\mathrm{n}=28)\end{array}$ & 0.011 & $0.005-0.043$ & $\begin{array}{l}0.006 \\
(\mathrm{n}=28)\end{array}$ & 0.0026 & $0.005-0.014$ \\
\hline Other berries & $\begin{array}{l}0.011 \\
(\mathrm{n}=7)\end{array}$ & 0.01 & $0.005-0.03$ & $\begin{array}{l}0.006 \\
(\mathrm{n}=7)\end{array}$ & 0.0027 & $0.005-0.011$ \\
\hline $\begin{array}{l}\text { Vegetables } \\
\text { (standard } 0.05 \mathrm{mg} \mathrm{kg}-1 \text { ) }\end{array}$ & $\begin{array}{l}0.008 \\
(\mathrm{n}=25)\end{array}$ & 0.0054 & $0.005-0.026$ & $\begin{array}{l}0.0072 \\
(\mathrm{n}=90)\end{array}$ & 0.0047 & $0.005-0.025$ \\
\hline Cabbage & $\begin{array}{l}0.009 \\
(\mathrm{n}=21)\end{array}$ & 0,006 & $0.005-0.026$ & $\begin{array}{l}0.006 \\
(\mathrm{n}=30)\end{array}$ & 0.0026 & $0.005-0.018$ \\
\hline $\begin{array}{l}\text { Others (onion, bean, } \\
\text { tomato...) }\end{array}$ & $\begin{array}{l}0.007 \\
(\mathrm{n}=4)\end{array}$ & 0.004 & $0.005-0.013$ & $\begin{array}{l}0.0079 \\
(\mathrm{n}=60)\end{array}$ & 0.0053 & $0.005-0.025$ \\
\hline 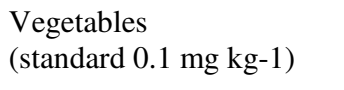 & $\begin{array}{c}0.085 \\
(n=41)\end{array}$ & 0.0767 & $0.005-0.320$ & $\begin{array}{l}0.0207 \\
(\mathrm{n}=69)\end{array}$ & 0.018 & $0.005-0.088$ \\
\hline Aspargus & $\begin{array}{l}0.009 \\
(\mathrm{n}=11)\end{array}$ & 0.004 & $0.005-0.015$ & $\begin{array}{l}0.011 \\
(\mathrm{n}=10)\end{array}$ & 0.009 & $0.005-0.032$ \\
\hline Leek & $\begin{array}{l}0.065 \\
(\mathrm{n}=5)\end{array}$ & 0.043 & $0.011-0.13$ & $\begin{array}{l}0.0143 \\
(\mathrm{n}=10)\end{array}$ & 0.008 & $0.005-0.025$ \\
\hline Carrot & $\begin{array}{l}0.124 \\
(\mathrm{n}=15)\end{array}$ & 0.073 & $0.043-0.32$ & $\begin{array}{c}0.03 \\
(\mathrm{n}=29)\end{array}$ & 0.02 & $0.005-0.088$ \\
\hline $\begin{array}{l}\text { Others (celery, } \\
\text { fennel, scorzonera...) }\end{array}$ & $\begin{array}{c}0.12 \\
(\mathrm{n}=10)\end{array}$ & 0.073 & $0.029-0.28$ & $\begin{array}{l}0.015 \\
(\mathrm{n}=20)\end{array}$ & 0.016 & $0.005-0.065$ \\
\hline $\begin{array}{l}\text { Vegetables } \\
\text { (standard } 0.2 \mathrm{mg} \mathrm{kg}-1 \text { ) }\end{array}$ & $\begin{array}{c}0.277 \\
(\mathrm{n}=31)\end{array}$ & N.A\$. & $0.07-1.20$ & $\begin{array}{l}0.0304 \\
(\mathrm{n}=68)\end{array}$ & 0.054 & $0.005-0.36$ \\
\hline Lettuce & N.A. & N.A. & N.A. & $\begin{array}{l}0.015 \\
(\mathrm{n}=27)\end{array}$ & 0.017 & $0.005-0.065$ \\
\hline $\begin{array}{l}\text { Others (spinach, } \\
\text { parsley, mushroom...) }\end{array}$ & N.A. & N.A. & N.A. & $\begin{array}{c}0.04 \\
(n=41)\end{array}$ & 0.067 & $0.005-0.36$ \\
\hline 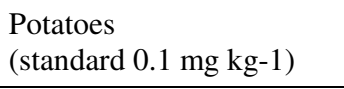 & $\begin{array}{l}0.051 \\
(\mathrm{n}=98)\end{array}$ & 0.0297 & $0.011-0.15$ & $\begin{array}{l}0.0209 \\
(\mathrm{n}=26)\end{array}$ & 0.014 & $0.005-0.067$ \\
\hline $\begin{array}{l}\text { Meat } \\
\text { (standard } 0.05 \mathrm{mg} \mathrm{kg}-1 \text { ) }\end{array}$ & $\begin{array}{c}0.004 \\
(\mathrm{n}=53)\end{array}$ & 0.004 & $0.001-0.019$ & $\begin{array}{c}0.002 \\
(\mathrm{n}=99)\end{array}$ & 0.003 & $0.001-0.021$ \\
\hline $\begin{array}{l}\text { Liver } \\
\text { (standard } 0.5 \text { mg kg-1) }\end{array}$ & $\begin{array}{l}0.446 \\
(\mathrm{n}=53)\end{array}$ & 0.473 & $0.055-2.66$ & $\begin{array}{l}0.203 \\
(\mathrm{n}=99)\end{array}$ & 0.159 & $0.029-0.854$ \\
\hline $\begin{array}{l}\text { Kidney } \\
\text { (standard } 1.0 \mathrm{mg} \mathrm{kg}-1 \text { ) }\end{array}$ & $\begin{array}{l}2.862 \\
(\mathrm{n}=53)\end{array}$ & 2.655 & $0.193-15.3$ & $\begin{array}{l}1.250 \\
(\mathrm{n}=99)\end{array}$ & 1.187 & 0.093-6.96 \\
\hline
\end{tabular}

*Standard refers to food or food group according to the European maximum limit.

\$N.A.: Not available. The Cd content of this food group has not been determined in the framework of this study but is derived from unpublished data owned by the Federal Agency for the Safety of the Food Chain. 
Table III. Local adult population in a polluted area - mean Cd concentration ( $\mathrm{mg} \mathrm{kg}^{-1}$ fresh weight) of food groups, daily $\mathrm{Cd}$ intake $\left(\mu \mathrm{g} \mathrm{day}^{-1}\right)$ by a $60-\mathrm{kg}$ adult living in a $\mathrm{Cd}$ polluted area, with an average consumption pattern or with a $97.5^{\text {th }}$ percentile consumption pattern, and percentage of the PTWI attained for each consumption pattern and food group.

\begin{tabular}{|c|c|c|c|c|c|}
\hline \multirow[b]{2}{*}{ Commodity } & \multirow[b]{2}{*}{$\begin{array}{l}\text { Mean Cd } \\
\text { concentration } \\
\mathrm{mg} \mathrm{kg}^{-1}\end{array}$} & \multicolumn{2}{|c|}{ Average consumption } & \multicolumn{2}{|c|}{$97.5^{\text {th }}$ percentile consumption } \\
\hline & & $\begin{array}{l}\text { Daily Cd } \\
\text { intake } \\
\mu \text { day }^{-1}\end{array}$ & $\%$ PTWI & $\begin{array}{l}\text { Daily Cd } \\
\text { intake } \\
\mu \mathrm{g} \mathrm{day}^{-1}\end{array}$ & $\%$ PTWI \\
\hline \multicolumn{6}{|l|}{ Fruit (all) } \\
\hline berries & 0.012 & 0.07 & 0.11 & 0.18 & 0.29 \\
\hline other fruit & 0.004 & 0.42 & 0.70 & 1.09 & 1.82 \\
\hline \multicolumn{6}{|l|}{ Vegetables (all) } \\
\hline $\begin{array}{l}\text { vegetables } \\
\left(\text { standard* } 0.05 \mathrm{mg} \mathrm{kg}^{-1}\right)\end{array}$ & 0.008 & 0.82 & 1.36 & 1.48 & 2.47 \\
\hline $\begin{array}{l}\text { vegetables } \\
\text { (standard } 0.1 \mathrm{mg} \mathrm{kg}^{-1} \text { ) }\end{array}$ & 0.085 & 1.95 & 3.24 & 3.54 & 5.90 \\
\hline $\begin{array}{l}\text { vegetables } \\
\left(\text { standard } 0.2 \mathrm{mg} \mathrm{kg}^{-1}\right)\end{array}$ & 0.277 & 4.55 & 7.57 & 8.27 & 13.8 \\
\hline Potatoes & 0.051 & 14.3 & 23.9 & 23.8 & 39.6 \\
\hline \multicolumn{6}{|l|}{ Meat (all) } \\
\hline poultry meat & 0.005 & 0.09 & 0.16 & 0.26 & 0.44 \\
\hline cattle meat & 0.004 & 0.27 & 0.45 & 0.51 & 0.85 \\
\hline pig meat & 0.007 & 0.39 & 0.65 & 0.73 & 1.22 \\
\hline \multicolumn{6}{|l|}{$\begin{array}{l}\text { Offal (all) } \\
\text { cattle offal }\end{array}$} \\
\hline kidney & 2.862 & 0.06 & 0.09 & 0.49 & 0.82 \\
\hline liver & 0.446 & 0.04 & 0.07 & 0.37 & 0.63 \\
\hline other offal & 0.063 & 0.01 & 0.02 & 0.10 & 0.17 \\
\hline Cereals & 0.023 & 4.47 & 7.45 & 9.25 & 15.4 \\
\hline Eggs & 0.003 & 0.03 & 0.05 & 0.08 & 0.14 \\
\hline $\begin{array}{l}\text { Milk \& milk products } \\
\text { (excluding cheese) }\end{array}$ & $0.410^{-3}$ & 0.07 & 0.11 & 0.19 & 0.32 \\
\hline Cheese & $0.910^{-3}$ & 0.03 & 0.05 & 0.07 & 0.11 \\
\hline Fish & 0.007 & 0.12 & 0.20 & 0.35 & 0.58 \\
\hline Seafood & 0.136 & 0.86 & 1.43 & 3.41 & 5.69 \\
\hline Oils and fats & 0.004 & 0.07 & 0.12 & 0.26 & 0.44 \\
\hline Other (e.g. sweets, sugar) & 0.009 & 2.66 & 4.43 & 8.88 & 14.81 \\
\hline Total & & 31.3 & 52.2 & 63.3 & 105.5 \\
\hline
\end{tabular}

*Standard refers to food or food group according to the European maximum limit. 
Table IV. General adult population - mean Cd concentration $\left(\mathrm{mg} \mathrm{kg}^{-1}\right.$ fresh weight) of food groups, daily $\mathrm{Cd}$ intake $\left(\mu \mathrm{g} \mathrm{day}^{-1}\right.$ ) by a $60-\mathrm{kg}$ adult living in a region at ambient $\mathrm{Cd}$ levels, with an average consumption pattern or with a $97.5^{\text {th }}$ percentile consumption pattern, and percentage of the PTWI attained for each consumption pattern and food group.

\begin{tabular}{|c|c|c|c|c|c|}
\hline \multirow[b]{2}{*}{ Commodity } & \multirow[b]{2}{*}{$\begin{array}{c}\text { Mean Cd } \\
\text { concentration } \\
\mathrm{mg} \mathrm{kg}^{-1}\end{array}$} & \multicolumn{2}{|c|}{ Average consumption } & \multicolumn{2}{|c|}{$97.5^{\text {th }}$ percentile consumption } \\
\hline & & $\begin{array}{l}\text { Daily Cd } \\
\text { intake }^{-1} \\
\mu \text { day }^{-1}\end{array}$ & $\%$ PTWI & $\begin{array}{l}\text { Daily Cd } \\
\text { intake }^{-1} \\
\mu \text { day }^{-1}\end{array}$ & $\%$ PTWI \\
\hline \multicolumn{6}{|l|}{ Fruit (all) } \\
\hline berries & 0.006 & 0.04 & 0.06 & 0.09 & 0.15 \\
\hline other fruit & 0.004 & 0.42 & 0.70 & 1.09 & 1.82 \\
\hline \multicolumn{6}{|l|}{ Vegetables (all) } \\
\hline $\begin{array}{l}\text { vegetables } \\
\left(\text { standard* } 0.05 \mathrm{mg} \mathrm{kg}^{-1}\right)\end{array}$ & 0.007 & 0.73 & 1.22 & 1.34 & 2.23 \\
\hline $\begin{array}{l}\text { vegetables } \\
\text { (standard } 0.1 \mathrm{mg} \mathrm{kg}^{-1} \text { ) }\end{array}$ & 0.021 & 0.47 & 0.79 & 0.86 & 1.44 \\
\hline $\begin{array}{l}\text { vegetables } \\
\left(\text { standard } 0.2 \mathrm{mg} \mathrm{kg}^{-1}\right)\end{array}$ & 0.031 & 0.50 & 0.83 & 0.91 & 1.51 \\
\hline Potatoes & 0.021 & 5.88 & 9.80 & 9.74 & 16.2 \\
\hline \multicolumn{6}{|l|}{ Meat (all) } \\
\hline poultry meat & 0.005 & 0.09 & 0.16 & 0.26 & 0.44 \\
\hline cattle meat & 0.002 & 0.14 & 0.23 & 0.26 & 0.43 \\
\hline pig meat & 0.007 & 0.39 & 0.65 & 0.73 & 1.22 \\
\hline \multicolumn{6}{|l|}{$\begin{array}{l}\text { Offal (all) } \\
\quad \text { cattle offal }\end{array}$} \\
\hline kidney & 1.250 & 0.03 & 0.04 & 0.22 & 0.36 \\
\hline liver & 0.203 & 0.02 & 0.03 & 0.17 & 0.28 \\
\hline other offal & 0.063 & 0.01 & 0.02 & 0.10 & 0.17 \\
\hline Cereals & 0.023 & 4.47 & 7.45 & 9.25 & 15.4 \\
\hline Eggs & 0.003 & 0.03 & 0.05 & 0.08 & 0.14 \\
\hline $\begin{array}{l}\text { Milk \& milk products } \\
\text { (excluding cheese) }\end{array}$ & $0.410^{-3}$ & 0.07 & 0.11 & 0.19 & 0.32 \\
\hline Cheese & $0.910^{-3}$ & 0.03 & 0.05 & 0.07 & 0.11 \\
\hline Fish & 0.007 & 0.12 & 0.20 & 0.35 & 0.58 \\
\hline Seafood & 0.136 & 0.86 & 1.43 & 3.41 & 5.69 \\
\hline Oils and fats & 0.004 & 0.07 & 0.12 & 0.26 & 0.44 \\
\hline Other (e.g. sweets, sugar) & 0.009 & 2.66 & 4.43 & 8.88 & 14.81 \\
\hline Total & & 17.0 & 28.4 & 38.3 & 63.8 \\
\hline
\end{tabular}

*Standard refers to food or food group according to the European maximum limit. 